IZA DP No. 10323

Empowering the Vulnerable to Be Entrepreneurs: An Empirical Test on the Effectiveness of the Ghana Microfinance Policy 2006

Luis Diaz-Serrano

Frank G. Sackey

October 2016 


\title{
Empowering the Vulnerable to Be Entrepreneurs: An Empirical Test on the Effectiveness of the Ghana Microfinance Policy 2006
}

\author{
Luis Diaz-Serrano \\ CREIP, Universitat Rovira i Virgili \\ and IZA \\ Frank G. Sackey \\ CREIP, Universitat Rovira i Virgili
}

Discussion Paper No. 10323

October 2016

\author{
IZA \\ P.O. Box 7240 \\ 53072 Bonn \\ Germany \\ Phone: +49-228-3894-0 \\ Fax: +49-228-3894-180 \\ E-mail: iza@iza.org
}

Any opinions expressed here are those of the author(s) and not those of IZA. Research published in this series may include views on policy, but the institute itself takes no institutional policy positions. The IZA research network is committed to the IZA Guiding Principles of Research Integrity.

The Institute for the Study of Labor (IZA) in Bonn is a local and virtual international research center and a place of communication between science, politics and business. IZA is an independent nonprofit organization supported by Deutsche Post Foundation. The center is associated with the University of Bonn and offers a stimulating research environment through its international network, workshops and conferences, data service, project support, research visits and doctoral program. IZA engages in (i) original and internationally competitive research in all fields of labor economics, (ii) development of policy concepts, and (iii) dissemination of research results and concepts to the interested public.

IZA Discussion Papers often represent preliminary work and are circulated to encourage discussion. Citation of such a paper should account for its provisional character. A revised version may be available directly from the author. 


\section{ABSTRACT}

\section{Empowering the Vulnerable to be Entrepreneurs: An Empirical Test on the Effectiveness of the Ghana Microfinance Policy 2006*}

The study aims at testing the Ghana Microfinance Policy set up to support the vulnerable through access to credit. We resort to the Blinder-Oaxaca decomposition to determine if there is positive discrimination in favor of women and young entrepreneurs in the rationing behavior of the microfinance companies. This is what we should expect if the policy is effective. Our results show that even after controlling for a large number of borrower characteristics, microfinance type and credit worthiness variables, there is positive discrimination that favors female and young entrepreneurs as this discrimination is largely determined by the differential treatment these groups receive in respect of men and older borrowers from microfinance institutions. Our results show that the Government microfinance is the most severe in the rationing behavior towards the discriminating groups.

JEL Classification: G21, J16

Keywords: microfinance, Ghana, credit rationing, positive discrimination

Corresponding author:

Luis Diaz-Serrano

Department of Economics

Universitat Rovira i Virgili

Av. Universitat 1

43204 Reus

Spain

E-mail: luis.diaz@urv.cat

\footnotetext{
* We acknowledge financial support from the Ministry of Economy and Competitiveness grant \#ECO2014-59055-R.
} 


\section{Introduction}

Issues relating to the vulnerable and access to credit in Ghana within the context of Ghana's Financial Sector Reforms have gained much prominence. The National Gender and Youth Policy was developed in 2004 with its overall goal in addressing gender and youth concerns into the national development process so as to improve the social, legal, political and economic wellbeing of women and the youth in particular. While the government of Ghana established an institutional structure aimed at promoting gender equality, the effectiveness of this goal suffered from weak institutional capacity (GHAMP, 2006). Policy makers in Ghana have now come to the realization that women and youth empowerment and access to resources by affirmative action through gender and youth prioritized policies rather than equality is the only way to addressing the challenges being faced by these vulnerable groups. In this regard, various policies, to the extent of setting up different Government Ministries for women and the youth have been implemented under various Governments. The setting up of the Ministry of Women's and Children's Affairs and later the Ministry of Women, Gender and Social Protection are in a bid to addressing the problems facing women and empowering them. The setting up of the Ministry of Youth and Sports that later changed to the Ministry of Manpower, Youth and Employment are also in a bid to making the youth employable and economically active. Various gender and youth empowerment intervention programmes were set up with the sole aim of empowering these vulnerable groups through access to resources, employment and other income generating activities but these programmes did not yield the required results.

In a bid to finding solutions to the problems confronting these vulnerable groups, the Ghana Government encouraged the promotion and development of the microfinance sector as a way of ensuring that women and young entrepreneurs meet their financial demands. The Ghana Microfinance Policy (GHAMP) was therefore developed in 2006 as a way of regularizing the operations of the MFIs in line with the objectives of the Ghana Government in reducing poverty and empowering women and young entrepreneurs who constitute the majority of the working 
population. Ghana's Microfinance Policy Document emphasizes the need for microfinance institutions to make credit more available and accessible to the vulnerable group of the society notably the youth and women. If the operations of the microfinance institutions are guided by this policy, then the gender and age gap in credit rationing, if there was any, must not be influenced by the borrowers' attributes and loan characteristics, but from a differential treatment of these attributes by microfinance institutions in favor of women and youth, i.e. positive discrimination. In this paper, our main objective is to determine the extent to which the operations of the microfinance companies are influenced by the Ghana Microfinance Policy. To do so we resort the Oaxaca decomposition method, which allow us to determine the extent to which potential difference in credit rationing between men and women, and between young and older entrepreneurs are due to differences in their credit worthiness characteristics or by an unequal treatment received from microfinance institutions. Unequal treatment in favor of women and the youth would imply positive discrimination. The data we use in order to test the effectiveness of the Ghana Microfinance Policy (2006) was gleaned from fourteen microfinance companies in Ghana: thirteen private and one governmental.

Our results show that the rationing and discrimination behavior of the microfinance companies favor women and young entrepreneurs, which means that the operations of the microfinance companies are influenced by the Ghana Microfinance Policy.

\section{Institutional Setting}

\subsection{Empowerment Programmes for Female and Young Entrepreneurs}

The Ministry of Women's and Children's Affairs in 2001 was the main vehicle for government programmes aimed at targeting poor women. The Ministry established the Women's Special Microfinance Fund with assistance from the Japanese government. The aim was to help in the development of women-owned enterprises, especially those in the rural and deprived areas, to augment their earnings from agricultural processing and marketing activities and to enable them 
access funds for future investments. The fund was disbursed through some of the microfinance institutions including the Rural and Community Banks. In addition, the Department of Youth Development within the Ministry of Youth and Sports and the Ministry of Employment and Social Welfare under the National Youth Employment Programme (NYEP) provided a number of training programmes for the poor and unemployed youth aged between 18 and 35 years. The intervention programme was basically to address the problem of the inadequate technical skills, lack of financial capital and the lack of labor market information.

Funds for youth development through the Communication Service Tax, was instituted in June 2008 through the Communication Service Tax Act (Act 754). This act had often been breached through diversion of funds collected for other competing uses. Funds were also made available through the Government microfinance company (MASLOC) and other microfinance companies for programme participants to access to buy inputs as well as to expand their microenterprises. This programme was later changed to the Ghana Youth Employment and Entrepreneurial Development Agency (GYEEDA) as a way of giving more attention to the youth in acquiring entrepreneurial skills and becoming economically independent. A grant of 65 million dollars was provided by the World Bank to strengthen youth entrepreneur projects under the collaboration between the then NYEP and the World Bank. Various models were established but surprisingly they became avenues through which political cronies siphoned monies by not using funds meant for the programme. Typical ones were the Agams and Jospong group of companies. It was therefore not surprising that a Presidential Commision set up to investigate the corruption at the Agency asked these two groups to refund various sums of monies to the state (Korboe David, 2014). The Rural Enterprise Programme (REP) was also part of government efforts aimed at reducing poverty and improving living conditions in the rural areas. It was a micro and small scale enterprises support system piloted in all the regions of Ghana with its development partners including IFAD and AFDB. The programme centered on technology transfer and access to rural and microfinance through linkages with participating financial institutions including Rural and 
Community Banks. Its gender strategy focused on supporting rural women's access to finance, skill training and capacity building. It also focused on Rural Youth Entrepreneurship interventions and approaches that aimed at attracting the youth to micro and small scale enterprises as a way of addressing youth unemployment. There was also the "Women in Agricultural Development” (WIAD), with its main objective of developing effective policies and programmes that support livelihood and wellbeing of women in Agriculture. It had collaborating institutions including the German International Agencies (GIZ), Canadian International Development Agency (CIDA), and USAID that provided funds for skill training and equipment.

Despite these efforts women, youth and other vulnerable groups remain marginalized as access to credit has become problematic to the extent that even funds meant to be disbursed through these intervention programmes do not reach them as these intervention programmes by governments have often been hugely politicized thereby failing to achieve the desired goals. According to the Ghana's population and Housing Census (2010) 90.9\% of the total female labor force is found in the private informal sectors that are discriminated against in access to formal credit. Compared with their older counterparts it has been observed that the youth in Ghana are 3.5 times more likely to be unemployed (Darvas et al, 2014; Gyampo, 2012; ISSER, 2012) with youth unemployment more than doubling since 1992).

\subsection{The Ghana Microfinance Policy (GHAMP)}

In 2006, the Ghana Microfinance Policy (GHAMP) was developed and implemented as the policy guideline for the microfinance intuitions in Ghana. The policy has its primary objectives that include; to create an enabling environment at the micro and macro levels that supports the operations of the sub-sector, to provide avenues for the sustainable flow of funds, adequate infrastructure and development of human capital, ensure an integrated and sustainable financial system that reaches and serves the poor, to facilitate activities that ensure consumer protection and to ensure a harmonized and coordinated sub-sector. The overall guiding principle was to 
introduce the microfinance sub-sector as an integral part of the financial sector development in Ghana. An additional guiding principles adapted from the Consultative Group to Assist the Poor (CGAP, 2006) that informed this policy were that; the Microfinance was a powerful tool for poverty reduction and economic development, its policies must be results-oriented and gender sensitive, adequate institutional arrangements be put in place so as to enhance the growth of the sub-sector, microfinance service providers operate in a competitive and coordinated environment.

The policy directions is that it shall seek to improve and deepen financial intermediation to serve the poor and low-income people by supporting and building of an inclusive, sustainable and efficient service system. The policy therefore has institutional arrangements, coordination and collaboration among the institutions within the sub-sector that minimizes duplication and foster complementarities of activities by all stakeholders within the industry.

The policy mandates microfinance institutions to make microcredit targeted and accessible to those who can use it productively and service debt. The policy specifically mandates microfinance institutions to provide savings, credit and other financial services to the vulnerable and the marginalized, which in the context of Ghana, have been identified to be women, the youth and the physically-challenged. The policy seeks to protect potential and actual end users of microfinance products and services from unfair practices such as exorbitant interest rates and ensures public disclosure and transparency in the operations of the institutions. To ensure that data and information gathering and dissemination are enhanced the Ghana Microfinance Institutions Network; an apex body that has been empowered to ensure the harmonization of information gathering, processing and dissemination of data in order to enhance the activities of the subsector through the creation of a central based system which will be accessible by all stakeholders.

To ensure proper and efficient regulation and supervision all MFIs seeking assistance from the government of Ghana or donor programmes shall require certification that it is a member in 
good standing with its respective sub-sector apex organization. All MFI Apex Bodies are to establish appropriate bye-laws, criteria for registration and standards, which shall be reviewed periodically in accordance with prevailing circumstances within the economy and in response to international practices and standards. To ensure effective monitoring and evaluation in line with the objectives of the policy, the following are being pursued; baseline studies on operations and outreach of institutions and a range of issues such as policies, institutional arrangements and regulatory mechanisms, operations research geared towards improving the efficiency of on-going projects and MFIs, collaborations with Universities and other research institutions in conducting periodic research into various aspects of the operations of the sub-sector and the development of key indicators for monitoring and evaluating the impact of programmes and activities and feedback mechanisms for review of implementation and policy. The government of Ghana, through the Ministry of Finance and Economic Planning shall monitor as well as provide progress report on the policy annually to stakeholders through the Microfinance Forum and at the end of every three years is the Microfinance Conference to review the policy.

\subsection{The Microcredit Application Process in Ghana}

The first stage of the loan application process is done in an informal manner. First the prospective applicant visits the microfinance company, have an interaction with the loan processing officer to ascertain his/her creditworthiness. Where the applicant is already in business and not loan for start-up the loan officer visits his/her business to familiarize himself with the business of the applicant. Where the loan officer is in doubts about the background or the business of the applicant the officer turns down the application and therefore no application forms is given to the prospective applicant to continue with the process. After the loan application form is given to the applicant he/she then supplies all the information therein and other requirements, submits the forms to the loans officer who will then examine and determine whether to partially or fully grant the amount being requested for. 
This informal application process makes it impossible to have information on the outright rejected applicants since such records are not taken by the loan officers of the microfinance companies. This situation means that we cannot control for sample selection in the application process. However, as we will discuss bellow, we do not expect this to be a serious problem for our empirical analysis.

\subsection{Review of Related Literature}

Recently studies about discrimination in the banking industry have gained much prominence in research. Few of these researches include, (Baydas et al, 1994; Blanchflower et al, 2003; DiazSerrano and Raya, 2014; Nti-Addae et al, 2012; Berkovec et al, 1998; Cavalluzzo et al; 2002). Discrimination in the financial markets occurs when the lender's decisions on loan applications are influenced by group membership such as gender, age or race of the borrower that are not relevant to the transaction. Becker (1957) notes that this type of discrimination diminishes as the financial market develops and competition becomes intense among lenders to the extent that they are no longer able to bear the cost of the non-economically motivated choices. An alternative model, the statistical model that counter Becker's argues that as long as borrowers' demographic characteristics are correlated with their credit worthiness, lenders may use the former as a proxy for the risk factor associated with loans. This is the case when lenders cannot observe the risk factors or unable to collect relevant information due to the cost involved (Phelps, 1972; Arrow, 1973). The severity of gender and age discrimination is often determined by the market condition in the country and in a more competitive loan market, lenders have less incentive to discriminate based on gender and age (Cavalluzzo et al, 2002; Berkovec et al, 1998). The majority of studies analyzing discrimination in credit markets generally focus on discrimination towards minorities such as black, Hispanic or immigrants. The literature aimed at analyzing discrimination against other more vulnerable groups, e.g. women and the youth, are much scarce. Andrea et al., (2010) observed that female entrepreneurs in Italy face tighter credit availability even though they do not 
pay higher interest rates, while Alberto et al. (2013) observed that women in Italy pay more for credit than men although they do not find evidence that women are riskier than men. Alexander et al. (2009) observed that in the UK female entrepreneurs were less likely to obtain a loan compared to their male counterparts and that female entrepreneurs were charged higher interest rates than their male entrepreneurs. Using US data, Mijid et al. (2013) observed that there is a higher loan denial rate and lower loan application rates for women compared to men. Similarly, Canton et al (2010), concluded that in the EU entrepreneurs age played an important role in that older entrepreneurs perceived external financing as less difficult

So far, evidence from developed countries shows that women and young are likely to be discriminated against in the loan market. In this context, one might expect the extent of this discrimination against women and young entrepreneurs to be amplified in developing countries. One of the reasons of why women and young entrepreneurs may experience difficulties in accessing credit regards to the lack of collateral, which also makes women and young people face legal obstacles in starting and running a business. According to World Bank report (2012) on Women and Business Law, women in Middle East and North African Countries have fewer inheritance rights than men. The reports also indicate that women have only one percent of the world's property and in two thirds of countries, legal rights of women decline with marriage. According to Agarwal (2003) biased inheritance rights often grant land to male relatives, leaving both widows and daughters at a disadvantage. In settings where adult men are perceived as breadwinners, young people and women's ability to offer family assets as collateral and the incentives to invest in productive activities are influenced by family dynamics that are likely to prioritize adult men's investments (Ospina, 1998). The above mentioned factors affect women and young people in the credit market especially the formal financial markets as they are used to deny them the amount of credit they require to run or set up their businesses thereby making them poorer and vulnerable. 
Although various researches have been conducted in the area of credit rationing and access to credit very little have explained the gender and youth characteristic aspects that influence the discrimination and rationing behavior of the MFIs. Most of these researches have also concluded that women and young people are often discriminated against in the credit markets. Khalid et al (2009) observe that in rural Zanzibar factors determining credit constrain were influenced by different characteristics for male and female borrowers. According to them, whereas wealth and risk bearing factors were significant for male borrowers, income levels were the significant factor for female borrowers. Zeller (1994), observed that young entrepreneurs were more likely to be rationed out of credit in his research in the informal financial markets in Madagascar during the period of 1993 and 1994. In a similar research Pariente (2005), observed that youth entrepreneurs are credit constraints compared to their older counterparts in Brazil. Using a sample of entrepreneurs in Ruiri Municipality of Kenya, Phylis et al., (2014) observed that women were less likely to obtain the required credit due to their low levels of literacy and lack of ownership of tangible assets and collateral. However, using data from 16 sub-Saharan African countries, Hansen et al (2014) observed that small enterprises owned by female entrepreneurs were less likely to be credit constrained compared to their male counterparts, whilst this was reversed for medium size enterprises, showing female favoritism for this type of firms. Fletscher (2008) observed that in Eastern Paraguay, women were more likely to be constrained than men, and that women's rationing status responds to a different set of factors than men. In a research to determine the extent of women access to credit constraints in Sri Lanka, Suresh et al., (2009) observed that gender gaps do not simply masks differences in ability, risk aversion, entrepreneurial attitudes or differences in reporting behavior, but there is some evidence that the gender gap is larger in female-dominated industries. 


\section{Empirical Framework: Testing for positive discrimination in favor of the vulnerable targeted in the Ghana Microfinance Policy 2006}

We assume that the credit rationing and the factors influencing the credit-rationing behavior of the microfinance institutions are determined by the following linear relationships:

$$
\mathrm{y}_{\mathrm{i}}=\beta^{\prime} \mathrm{X}_{\mathrm{i}}+\varepsilon_{\mathrm{i}}
$$

where the outcome $y_{i}$ can be either a dummy variable that takes the value one if the loan amount requested is not fully granted and zero otherwise, or the share of the total amount requested that has been granted. When our outcome variable $y_{i}$ is binary, we may estimate the probability of being credit rationed resorting to the probit or the linear probability model (LPM). In the second case, when the outcome variable $y_{i}$ is a proportion, we may estimate equation (1) using the probit and the OLS estimation method.

In equation (1) the matrix $\mathrm{X}$ contains a set of variables picking up the credit worthiness of the loan, borrower's characteristics and the type of microfinance institution granting the loan. The borrowers characteristics included in the model are experience (the number of years in business), education (the level of formal education), profession (the sector of business), assets (the value of assets of the business), profits (the monthly profits of the business), collateral (the value of collateral), location (the distance from the firm to the microfinance company), guarantor (an individual promising to pay in the case of default), relationship(whether borrower has contracted a loan with the microfinance company before), purpose(whether the requested loan is meant for the business or other purpose), maturity(the number of months for the repayment of loan), savings (whether mandatory of non-mandatory savings) and interested rate(the amount of loan accepted by the borrower). The type of microfinance institution include savings and loans (microfinance 1,2 and 3) the government's microfinance (microfinance 4), the NGO type 
(microfinance 5, 6, 7, 8 and 9) and the community and rural banks (microfinance 10, 11, 12, 13 and 14). The vector $\beta$ contains the set of parameters to be estimated and the $\varepsilon$ is random term with the standard distributional properties in each case. The vector of estimated parameters $\beta$ reflects the marginal contribution of each factor to the probability of being rationed or to the size of the rationing.

The Ghana microfinance Policy among other things, entreats the microfinance companies to give priority to the vulnerable, namely, women and the youth in the granting of microcredit. The policy therefore expects the microfinance companies to first consider women and young entrepreneurs before any other groups of applicants. In other words, we should expect to detect positive discrimination in favor of these vulnerable groups.

We rewrite now equation (1) as follows:

$$
\mathrm{y}_{\mathrm{ij}}=\beta_{\mathrm{j}} \mathrm{X}_{\mathrm{ij}}+\varepsilon_{\mathrm{ij}}
$$

where in equation (2) the subscript $\mathrm{j}$ reflects the belonging to a certain population group, e.g. male and female, or young and older borrower. Assume $\mathrm{j}=\mathrm{m}$ for men, and $\mathrm{j}=\mathrm{w}$ for women, and also, $\beta_{\mathrm{m}}$ and $\beta_{\mathrm{w}}$ the marginal effects in each case. Discrimination will exist if males and females are treated differently by microcredit institutions in those relevant variables $\left(\mathrm{X}_{\mathrm{ij}}\right)$ determining the rationing of a credit, that is, if $\beta_{\mathrm{m}} \neq \beta_{\mathrm{w}}$. The necessary assumption is that the distribution of unobservables $\varepsilon_{\mathrm{ij}}$ is independent of individual $\mathrm{i}$ belonging to group $\mathrm{j}=\mathrm{m}$ or $\mathrm{j}=\mathrm{f}$. In this context, discrimination can be either in favor of or against a specific group. In this study, our assumption is that if the Ghana Microfinance Policy 2006 is being effective, there should be positive discrimination in favor of the vulnerable targeted groups, i.e. women and young borrowers, in respect to their men and older counterparts. 
Suppose the coefficients $\beta_{\mathrm{cm}}$ and $\beta_{\mathrm{cw}}$ to be the marginal effect of the collateral on the probability of being rationed for men and women, respectively positive discrimination in favor of women would require that for each additional unit of collateral, the probability being rationed decreases more for women than for men, that is, $\left|\beta_{\mathrm{cw}}\right|>\left|\beta_{\mathrm{cm}}\right|$. If a difference in the credit rationing between men and women was observed, in the absence of discrimination $\left(\beta_{\mathrm{m}}=\beta_{\mathrm{w}}\right)$, then this differences would be attributable to the fact that one group is endowed with a set of characteristics that makes lenders to consider credit worthiness better, or less risky for one of the two groups, i.e. $X_{\mathrm{im}} \neq \mathrm{X}_{\mathrm{iw}}$.

In order to carry our test on the effectiveness of the Ghana Microfinance Policy 2006, we resort to the Oaxaca-Blinder decomposition. ${ }^{1}$ This method allows us to quantify the role of the observables $X_{\mathrm{ij}}$ (endowments) and coefficients $\beta_{\mathrm{j}}$ (discrimination) in explaining the credit rationing gap between two groups, namely vulnerable (v) and non-vulnerable (nv). With the Oaxaca-Blinder method, we can decompose the estimated gap in the credit rationing between the vulnerable $\left(\mathrm{y}_{\mathrm{v}}\right)$ and the non-vulnerable $\left(\mathrm{y}_{\mathrm{nv}}\right)$ into two components as follows:

$$
\hat{\mathrm{Y}}_{\mathrm{nv}}-\hat{\mathrm{Y}}_{\mathrm{v}}=\left(\overline{\mathrm{X}}_{\mathrm{nv}}-\overline{\mathrm{X}}_{\mathrm{v}}\right) \hat{\beta}_{\mathrm{v}}-\overline{\mathrm{X}}_{\mathrm{v}}\left(\hat{\beta}_{\mathrm{nv}}-\hat{\beta}_{\mathrm{v}}\right)
$$

The left hand side of Eq. (3) measures the estimated gap in credit rationing between the two groups. The first term on the right hand side picks up the part of the gap attributable to differences in the endowments between both groups (loan, borrower and lender characteristics), whilst the second term concerns the part of the gap caused by differences in the coefficients (discrimination). The latter picks up differences in the treatment that lenders give to the vulnerable and the nonvulnerable.

\footnotetext{
${ }^{1}$ See Blinder (1973) and Oaxaca (1973)
} 
It could be the case that there is no gap between both groups. In this case, equation 3 is still useful to test for discrimination. It is possible that differences in the in the endowments between both groups are canceled out by a disparate treatment. This might explain why there could be no gap in the average outcomes in the presence of discrimination, either in favor or against specific population group.

\section{The Data}

The data for the study was gleaned from the 14 microfinance companies of the various microfinance institutions and consisted of 1,429 borrowers. The data on these 1429 borrowers comprised of their individual socio-economic characteristics, firm and loan characteristics and their status regarding the supply of credit (whether rationed or not rationed) during the period 2012 and 2013. Gathering information on borrowers turned down in the loan application process was not possible as loan application from the microfinance institutions in Ghana first begins with interactions with the credit officer to ascertain the credit worthiness of the borrower before the application forms are handed to the prospective borrower. Where the credit officer find the borrower very risky the application is turned down and hence no application form is given to the borrower and therefore no information on the borrower is gathered. The non- availability of credit bureaus also made it difficult to obtain more data on borrowers and hence large sample size as this had to be done at the individual microfinance level and depended on the willingness of these microfinance companies to provide such information. None the less the number of microfinance companies according to the microfinance types used for the study and fairly distributed based on mix market (2012), both at the regional and national level. We therefore do not anticipate any biasedness with regards to our sampling.

The variables for the study were therefore entered and coded as follows; maturity (the duration for the repayment of the loan in months), savings (non-mandatory savings of the applicant) that takes the value " 0 " if applicant has non-mandatory savings and " 1 " if otherwise, 
interest rates (interest on loan charged per month), assets (value of the assets of the business in monetary terms), profits (monthly profits declared in monetary terms). The variable, purpose(purpose of the loan) that takes the value "o" if directly related to the business and " 1 " if otherwise, collateral(the value of fixed or movable assets confiscable in case of default), guarantor( a person guaranteeing to pay up the loan with interest in the case of default and absence of collateral) that takes the value " 0 " if applicant provides a guarantor and " 1 " if otherwise), location(the distance from the business to the microfinance) which also takes the value " $\mathrm{O}$ " if the business or applicant is closer to the microfinance company and " 1 " if otherwise. Gender takes the value " 1 " if female and "o" if male, youth (if age between 18 and 35 based on the Ghana Youth Policy) takes the value of "1" if youth and "o" if otherwise. Education(level of formal education attained) ranked as " 1 " if tertiary, " 2 " if secondary, " 3 " if Primary and " 4 " if no formal education, sector( the sector in which the applicant operates his business), ranked "1" if commerce, " 2 " if transport, " 3 " if manufacturing, " 4 " if agriculture and " 5 "if service, relationship with lender that takes the value as " 1 " if applicant is a first time borrower and "o" otherwise, experience in business being the number of years the applicant has been in business constituting the individual characteristics. Also included in the model are the microfinance dummies for the microfinance companies according to their institutional types.

In table (1) we report the descriptive statistics of our sampled data. Our data confirms the MIX (2012) report on the microfinance market in Ghana which reports that almost $60 \%$ of the microfinance clients are women both at the regional and the national level. Comparatively more male are rationed. This is similar to the observations made by Henrik et al (2011) who observed that more women are less likely to be rationed compared to their male counterpart for Ghana. Our data also show that relatively small number of young borrowers was rationed (28.8\%) compared to their adult counterpart of (40.82\%).

The distribution of borrowers according to sectors shows more women to be in the agric and commerce sectors whilst more men were found in the manufacturing sector. This also 
confirms the Ghana Living Standard Survey (GLSS6) report of the Ghana statistical service that found comparatively more women in the commerce and agric sector and more men in the manufacturing sector. Proportionately more young borrowers constitute the commerce and service sectors whilst relatively more adults are found in the transport and manufacturing sectors. This is not surprising since the youth do not have the necessary capital to venture into the transport and manufacturing sector that requires huge capital for startup. More females have attained tertiary education (51.8\%) whilst their male counterparts have only $47.59 \%$ that have tertiary education. The illiteracy rate for females was only $2.11 \%$ whilst that of the males was 5.14\%. This gap may be attributed to the Girl Child Education policy and the free compulsory Basic Education (FCUBE) that were implemented some two decades ago. In the same vein we found the illiteracy rate for young borrowers to be only $1.45 \%$ whilst that of adults was $4.68 \%$.

On the average men and adults have relatively high value of assets and collateral whilst their female and younger counterparts have relatively low value of assets and collateral. It is therefore not surprising that female and young borrowers provided more guarantors (74\%) and (76.6\%) respectively whilst their male and adult counterparts were $71 \%$ and $70.4 \%$ respectively. This is not surprising as in the Ghanaian social and cultural set up family assets and properties are inherited by the male members whilst most of these assets and properties are also entrusted to the head of the households who can offer them as collateral. Apart from the NGO microfinance type that served comparatively more adult borrowers, almost same proportions for young and adult borrowers were served by the other three microfinance types. With regards to the female and male groups the savings and loans microfinance type served proportionately same amount of females and males whilst the government type and the community and rural banks served more women whilst the NGO type serve comparatively more men. 
Table 1: Descriptive Analysis of Data

\begin{tabular}{|c|c|c|c|c|c|}
\hline & Description & Female & Male & Youth & Adult \\
\hline Rationed & $\begin{array}{l}\text { Borrowers who } \\
\text { received only part of } \\
\text { the amount requested }\end{array}$ & $279(34.6)$ & $238(38.3)$ & $159(28.8)$ & $358(40.82)$ \\
\hline \multirow{5}{*}{$\begin{array}{l}\text { Business sector } \\
\text { of borrower }\end{array}$} & Commerce & $319(39.53)$ & $216(34.73)$ & $236(42.75)$ & 299(34.09) \\
\hline & Transport & $47(5.82)$ & $36(5.79)$ & $19(3.44)$ & $64(7 \cdot 30)$ \\
\hline & Manufacturing & $84(10.41)$ & $107(17.20)$ & $49(8.88)$ & 142(16.19) \\
\hline & Agriculture & 243(30.11) & $154(24.76)$ & $147(26.63)$ & $250(28.51)$ \\
\hline & Service & $114(14.13)$ & $109(17.52)$ & 101(18.3) & $122(13.91)$ \\
\hline \multirow{4}{*}{$\begin{array}{l}\text { Borrower's } \\
\text { educational } \\
\text { level }\end{array}$} & Tertiary & $418(51.8)$ & $296(47.59)$ & $292(52.9)$ & $422(48.12)$ \\
\hline & Secondary & $185(22.92)$ & $114(18.33)$ & $103(18.66)$ & $196(22.35)$ \\
\hline & Primary & 187(23.17) & 180(28.94) & 149(26.99) & $218(24.86)$ \\
\hline & Illiterate & $17(2.11)$ & $32(5.14)$ & $8(1.45)$ & $41(4.68)$ \\
\hline \multirow{2}{*}{$\begin{array}{l}\text { Classification } \\
\text { of monthly } \\
\text { interest rates } \\
\end{array}$} & Low (2-3\%) & $177(21.93)$ & $75(12.06)$ & $80(14.49)$ & $172(19.61)$ \\
\hline & $\operatorname{High}(3.5-4.5)$ & $630(78.07)$ & $547(87.94)$ & $472(85 \cdot 51)$ & $705(80.39)$ \\
\hline Guarantor & Guarantor provided & $597(73.98)$ & $443(71.22)$ & $423(76.63)$ & $617(70.35)$ \\
\hline Relationship & $\begin{array}{l}\text { Borrowed in the past } \\
\text { more than once in the } \\
\text { same MFI }\end{array}$ & $327(40.52)$ & $253(40.68)$ & $232(42.03)$ & $348(39.68)$ \\
\hline Microfinance1 & Savings and Loans & $58(7.19)$ & 73(11.74) & $79(14 \cdot 31)$ & $52(5.93)$ \\
\hline Microfinance2 & & $82(10.16)$ & $34(5 \cdot 47)$ & $46(8.33)$ & $70(7.98)$ \\
\hline Microfinance3 & & $71(8.80)$ & $54(8.68)$ & $26(4 \cdot 71))$ & $99(11.29)$ \\
\hline Microfinance4 & Governmental & $106(13.14)$ & $21(3 \cdot 34)$ & $54(9.78)$ & $73(8.32)$ \\
\hline Microfinance 5 & NGO & $67(8.30)$ & $33(5 \cdot 31)$ & $38(6.88)$ & $62(7.07)$ \\
\hline Microfinance6 & & $25(3.10)$ & $75(12.06)$ & $20(3.62)$ & $80(9.12)$ \\
\hline Microfinance7 & & $44(5 \cdot 4)$ & $56(9.00)$ & $34(6.16)$ & $66(7.53)$ \\
\hline Microfinance8 & & 49(6.07) & $57(9.16)$ & $35(6.34)$ & $71(8.10)$ \\
\hline Microfinance9 & & $44(5 \cdot 45)$ & $62(9.97)$ & $51(9.24)$ & $55(6.27)$ \\
\hline Microfinance10 & Rural and & $41(5.08)$ & $29(4.66)$ & $38(6.88)$ & $32(3.65)$ \\
\hline Microfinance11 & Community Banks & $47(5.82)$ & $26(4.18)$ & 22(3.99) & $51(5.82)$ \\
\hline Microfinance12 & & $44(5 \cdot 45)$ & $21(3 \cdot 38)$ & $37(6.70)$ & 28(3.19) \\
\hline Microfinance13 & & $81(10.04)$ & $47(7.56)$ & $55(9.96)$ & $73(8.32)$ \\
\hline Microfinance14 & & $48(5.95)$ & $34(5.47)$ & $17(3.08)$ & $65(7.41)$ \\
\hline Observations & & 807 & 622 & 522 & 877 \\
\hline
\end{tabular}




\section{Econometric Results}

\subsection{The Probability of being rationed}

In table 2, we show the estimated effects of the determinants of the probability of being credit rationed. To allow for interpretation, we report the marginal effects instead of the estimated coefficients. The size of the rationing and the direction will be determined by the marginal effects and their signs, whilst the significance or otherwise will be determined by their corresponding pvalues. Our estimation strategy consists of introducing each set of variables sequentially to see how the membership group dummy (women/young) evolves as we include each group of covariates. We start with the most parsimonious model, which only includes a set of dummy variables identifying the group policy variables (column 1). In columns 2 and 3 , we repeat the same sequential procedure, but now we include the individual characteristics, the firm and finally the loan characteristic. In column 4, we add the dummies for the microfinance companies to test whether within the microfinance companies we can observe some heterogeneity across them regarding the borrowers who are credit rationed.

Our general results support the existing theory and other empirical studies (Alberto et al, 2013; Alexander et al, 2009; Hansen et al, 2014; Khalid et al, 2009) since all the control variables behave according to expectations. We start commenting on the results of the models considering dummies for the policy group variables. In column (1), without other covariates than the youth dummy, the female dummy as a policy variable, both was negative though not statistically significant. However, once we include individual characteristics (column 2) the female dummy variable remains negative and becomes statistically significant, though only at $10 \%$ level. Once we control for the credit worthiness of the loan (column 3), the probability of being credit rationed falls up to 6.7 percentage points for females and the effect becomes statistically significant at $5 \%$

level. Finally, the probability of being credit rationed falls in almost 8 percentage points as we introduce the dummies for the microfinance companies, being the government microfinance 
company the base category (column 4). In the most parsimonious model in column 1 , the female dummy variable was not significant, which indicates the inexistence of the credit rationing gender gap. However, the fact that the marginal effect associated to this variable becomes statistically significant as we control for individual and loan characteristics suggests that the treatment that women receive from microfinance institutions might differ from the treatment received by their male borrower counterparts.

The behavior exhibited by the marginal effect associated to the youth policy variable was however quite different to the female case. The effect for the youth dummy is statistically significant at $1 \%$ level and almost constant across alternative models. In the most parsimonious model reported in column (1), without additional controls than the female dummy, the probability of being credit rationed decreases in 12 percentage points for young borrowers and decreases further to 13 percentage points once we include individual characteristics (column 2). In column (3), after controlling for the credit worthiness of the loan, the probability of being credit rationed for youth decreases in 11.3 percentage points, but reduces further to almost 12 percentage points (as in column 1) after including the dummies for the microfinance companies, being again the government type the base category (column 4).

With regards to the borrower's individual characteristics, we will focus on the results of the full model reported in column (4). We observe that for each additional year of experience the probability of being credit rationed decreases in 1.3 percentage points. The probability of being credit rationed increases in 48.6 percentage points for a borrower with no formal education. For borrowers operating in the manufacturing industry the probability of being credit rationed is 11.4 percentage points smaller. On the contrary, working in the agriculture industry increases the borrower's probability of being credit rationed in 15.2 percentage points.

The amount of borrower's declared profits in his/her activity has turned out not to be statistically significant. However, the amount of collateral and assets exhibit an inverted U-shaped effect on the probability of being credit rationed. That is, the impact of these variables on credit 
rationing becomes negative only after a given amount of collateral and assets. For those borrowers who are required to provide a guarantor, the probability of being credit rationed increases in 25 percentage points. This is so because the need of guarantor indicates that the risk of the loan is perceived to be high by the lender. Having savings and a previous relationship with the lender also decreases significantly the probability of being credit rationed in 25 and 11.7 percentage points, respectively. It is also worth noting that, the government MFI is the one which is practicing credit rationing more intensively. With few exceptions, with respect to other non-governmental MFIs, the probability of being rationed by the government MFI is between 17 and 30 percentage points higher. We find this result a bit odd, since is the governmental MFI the one who seems to be acting against the Ghana Microfinance Policy promoted by the government of Ghana. 
Table 2: Determinants of the probability of being credit rationed (Probit model)

\begin{tabular}{|c|c|c|c|c|}
\hline & (1) & (2) & (3) & (4) \\
\hline \multirow[t]{2}{*}{ Female } & -0.0348 & $-0.0477 *$ & $-0.0676 * *$ & $-0.0792 * * *$ \\
\hline & $(0.0258)$ & $(0.0266)$ & $(0.0283)$ & $(0.0298)$ \\
\hline \multirow[t]{2}{*}{ Youth } & $-0.120 * * *$ & $-0.131 * * *$ & $-0.113 * * *$ & $-0.120 * * *$ \\
\hline & $(0.0255)$ & $(0.0267)$ & $(0.0280)$ & $(0.0289)$ \\
\hline \multirow[t]{2}{*}{ Experience } & & $-0.0121 * * *$ & $-0.0145 * * *$ & $-0.0130 * * *$ \\
\hline & & $(0.00306)$ & $(0.00321)$ & $(0.00367)$ \\
\hline \multirow[t]{2}{*}{ Secondary } & & 0.0604 & 0.0186 & $0.0800^{*}$ \\
\hline & & $(0.0381)$ & $(0.0400)$ & $(0.0461)$ \\
\hline \multirow[t]{2}{*}{ Primary } & & 0.0121 & -0.0515 & -0.0391 \\
\hline & & $(0.0356)$ & $(0.0362)$ & $(0.0382)$ \\
\hline \multirow[t]{2}{*}{ Illiterate } & & $0.260 * * *$ & $0.486 * * *$ & $0.486 * * *$ \\
\hline & & $(0.0795)$ & $(0.0790)$ & $(0.110)$ \\
\hline \multirow[t]{2}{*}{ Transport } & & $0.143 * *$ & -0.0135 & -0.0312 \\
\hline & & $(0.0621)$ & $(0.0614)$ & $(0.0622)$ \\
\hline \multirow[t]{2}{*}{ Manufacturing } & & -0.0599 & $-0.0972 * *$ & $-0.114 * *$ \\
\hline & & $(0.0431)$ & $(0.0452)$ & $(0.0451)$ \\
\hline \multirow[t]{2}{*}{ Agriculture } & & $0.174 * * *$ & $0.190 * * *$ & $0.152 * * *$ \\
\hline & & $(0.0379)$ & $(0.0433)$ & $(0.0455)$ \\
\hline \multirow[t]{2}{*}{ Service } & & -0.0509 & 0.00422 & 0.0389 \\
\hline & & (0.0399) & $(0.0459)$ & $(0.0492)$ \\
\hline \multirow[t]{2}{*}{ Collateral } & & & $2.60 \mathrm{e}-05^{* * *}$ & $1.60 \mathrm{e}-05^{* *}$ \\
\hline & & & $(6.65 e-06)$ & $(7.56 \mathrm{e}-06)$ \\
\hline \multirow[t]{2}{*}{ Collateral sq. } & & & $-7.46 \mathrm{e}-10 * * *$ & $-5.89 \mathrm{e}-10 * *$ \\
\hline & & & $(2.46 \mathrm{e}-10)$ & $(2.71 \mathrm{e}-10)$ \\
\hline \multirow[t]{2}{*}{ Assets value } & & & $3.17 \mathrm{e}-06$ & $1.48 \mathrm{e}-05 * * *$ \\
\hline & & & $(4.46 e-06)$ & $(4.85 \mathrm{e}-06)$ \\
\hline \multirow{2}{*}{ Assets value sq. } & & & $-5.60 e-11$ & $-1.90 \mathrm{e}-10 * *$ \\
\hline & & & $(6.91 \mathrm{e}-11)$ & $(7.80 \mathrm{e}-11)$ \\
\hline \multirow[t]{2}{*}{ Declared profits } & & & $1.51 \mathrm{e}-05$ & $2.57 \mathrm{e}-06$ \\
\hline & & & $(2.36 \mathrm{e}-05)$ & $(2.51 \mathrm{e}-05)$ \\
\hline \multirow[t]{2}{*}{ Declared profits sq. } & & & $-1.11 \mathrm{e}-10$ & $9.64 \mathrm{e}-10$ \\
\hline & & & $(1.85 \mathrm{e}-09)$ & $(1.95 \mathrm{e}-09)$ \\
\hline \multirow[t]{2}{*}{ Location } & & & 0.0236 & 0.0354 \\
\hline & & & $(0.0288)$ & $(0.0300)$ \\
\hline \multirow[t]{2}{*}{ Guarantor } & & & $0.273 * * *$ & $0.248 * * *$ \\
\hline & & & $(0.0351)$ & $(0.0431)$ \\
\hline \multirow[t]{2}{*}{ Relationship } & & & $-0.0925 * * *$ & $-0.117 * * *$ \\
\hline & & & $(0.0279)$ & $(0.0286)$ \\
\hline \multirow[t]{2}{*}{ Purpose } & & & -0.0467 & -0.0312 \\
\hline & & & $(0.0309)$ & $(0.0316)$ \\
\hline \multirow[t]{2}{*}{ Savings } & & & $-0.264 * * *$ & $-0.248 * * *$ \\
\hline & & & $(0.0418)$ & $(0.0653)$ \\
\hline \multirow[t]{2}{*}{ Maturity } & & & $0.0163 * * *$ & $0.0192 * * *$ \\
\hline & & & $(0.00310)$ & $(0.00338)$ \\
\hline
\end{tabular}


Type of MFI (base Governmental)

Savings and Loans

MFI 1

$-0.172 * * *$

(0.0480)

MFI 2

$-0.288 * * *$

(0.0306)

MFI 3

$-0.176^{* * * *}$

(0.0464)

NGO

MFI 5

$-0.304 * * *$

(0.0296)

MFI 6

$-0.216^{* *}$

$(0.0908)$

MFI 7

$-0.101$

$(0.0622)$

MFI 8

$-0.263 * * *$

$(0.0343)$

MFI 9

$-0.0939$

$(0.0633)$

Rural and Community Bank

MFI 10

$-0.240 * * *$

$(0.0427)$

MFI 11

$-0.0640$

$(0.0757)$

MFI 12

0.141

(0.0968)

MFI 13

0.0149

$(0.0637)$

MFI 14

$-0.0830$

(0.0681)

Observations 1,429

1,429

1,429

1,429

Notes: Significance, ${ }^{*}(10 \%),{ }^{* *}(5 \%),{ }^{* * *}(1 \%)$; Marginal effects reported instead of coefficients; standard errors in parentheses. 


\subsection{Testing for discrimination}

\subsubsection{Group interactions regressions}

In this subsection we discuss the marginal effects of the coefficients of the various groups. That is, we estimate separate regressions for women and men, and for adult and young borrowers. This analysis is carried out in order to observe the extent to which estimated marginal effects are different between men and women, and between young and older borrowers. If estimated marginal effects for the determinants of the probability of being credit rationed significantly differ between both groups (women vs. men and young vs. older), the hypothesis of discrimination cannot be rejected. In case that discrimination favors female and young borrowers, then this would imply the existence of positive discrimination, and we can conclude the Ghana Microfinance Policy 2006 is being effective.

In table (3), column (1) we report the marginal effects of our estimation when borrowers are males; column (2) reports same when borrowers are females, column (3) when borrowers are adults and column (4) when borrowers are youth. We discuss columns (1) and (2) concurrently and same for columns (4) and (5). In columns (1) and (2) we observe that the probability of being credit rationed reduces in 14.6 percentage points for female young borrowers, in respect to older female, and this effect being statistically significant at $1 \%$ level. For young men, compared with their older men counterparts, the probability of being credit rationed decreases in 8 percentage points, and this effect being only significant at 10\% level. Analogously, among young borrowers, women are 12.7 percentage points less likely to be credit rationed than men, while for older borrowers the gender gap is still negative in favor of women but not statistically significant. These results are quite revealing, since they indicate that young women (the intersection of both targeted groups) are the group that has a smaller probability of being credit rationed.

For the sake of brevity, we will not comment all the results regarding all variables for all groups. In all population groups the sign of the significance for most of the variables coincides with the results provided by the pooled model reported in table 2. A first look at the results 
reported in Table 3 suggests that male and female borrowers are treated differently by MFIs in Ghana, since for a number of variables estimated marginal effects look very different between men and women, and between young and older borrowers. Indeed, marginal effects associated to most of the microfinance institutions dummies are generally statistically significant across groups, and also apparently different when we compare men vs. women and young vs. older borrowers. In order to statistically test the extent to which men and women, and young and older borrowers are treated differently, we resort to the decomposition analysis introduced in section 3, which results are presented in the next subsection 4.2.2. 
Table 3: Interactions of Group Specific Regression (Probit)

\begin{tabular}{|c|c|c|c|c|}
\hline & $\begin{array}{c}(1) \\
\text { male }\end{array}$ & $\begin{array}{c}(2) \\
\text { female }\end{array}$ & $\begin{array}{c}\text { (3) } \\
\text { adult }\end{array}$ & $\begin{array}{c}\text { (4) } \\
\text { youth }\end{array}$ \\
\hline Female & & & $\begin{array}{l}-0.0448 \\
(0.0406)\end{array}$ & $\begin{array}{c}-0.127 * * * \\
(0.0451)\end{array}$ \\
\hline Youth & $\begin{array}{l}-0.0797 \\
(0.0486)\end{array}$ & $\begin{array}{c}-0.146^{* * *} \\
(0.0383)\end{array}$ & & \\
\hline Experience & $\begin{array}{c}-0.0142^{* *} \\
(0.00615)\end{array}$ & $\begin{array}{c}-0.0165^{* * *} \\
(0.00499)\end{array}$ & $\begin{array}{c}-0.0158^{* * *} \\
(0.00438)\end{array}$ & $\begin{array}{c}0.00312 \\
(0.00890)\end{array}$ \\
\hline Secondary & $\begin{array}{l}0.213 * * \\
(0.0876)\end{array}$ & $\begin{array}{l}-0.00904 \\
(0.0596)\end{array}$ & $\begin{array}{l}0.151 * * \\
(0.0636)\end{array}$ & $\begin{array}{l}-0.0231 \\
(0.0636)\end{array}$ \\
\hline Primary & $\begin{array}{c}-0.0350 \\
(0.0631)\end{array}$ & $\begin{array}{c}-0.0678 \\
(0.0503)\end{array}$ & $\begin{array}{l}0.00534 \\
(0.0539)\end{array}$ & $\begin{array}{c}-0.0640 \\
(0.0535)\end{array}$ \\
\hline Illiterate & $\begin{array}{c}0.617 * * * \\
(0.0771)\end{array}$ & $\begin{array}{c}-0.0304 \\
(0.231)\end{array}$ & $\begin{array}{c}-0.0379 \\
(0.178)\end{array}$ & \\
\hline Transport & $\begin{array}{c}0.133 \\
(0.111)\end{array}$ & $\begin{array}{l}0.000137 \\
(0.0994)\end{array}$ & $\begin{array}{l}-0.0209 \\
(0.0824)\end{array}$ & $\begin{array}{c}-0.143^{* *} \\
(0.0694)\end{array}$ \\
\hline Manufacturing & $\begin{array}{c}0.0511 \\
(0.0895)\end{array}$ & $\begin{array}{c}-0.214 * * * \\
(0.0485)\end{array}$ & $\begin{array}{l}-0.109^{*} \\
(0.0605)\end{array}$ & $\begin{array}{c}-0.142^{* *} \\
(0.0576)\end{array}$ \\
\hline Agriculture & $\begin{array}{c}0.353^{* * *} \\
(0.0785)\end{array}$ & $\begin{array}{c}0.0803 \\
(0.0594)\end{array}$ & $\begin{array}{c}0.0557 \\
(0.0602)\end{array}$ & $\begin{array}{c}0.223 * * * \\
(0.0776)\end{array}$ \\
\hline Service & $\begin{array}{c}0.0238 \\
(0.0783)\end{array}$ & $\begin{array}{c}0.0590 \\
(0.0692)\end{array}$ & $\begin{array}{l}-0.0354 \\
(0.0642)\end{array}$ & $\begin{array}{c}0.109 \\
(0.0788)\end{array}$ \\
\hline Collateral & $\begin{array}{c}5.06 \mathrm{e}-06 \\
(1.05 \mathrm{e}-05)\end{array}$ & $\begin{array}{c}3.06 \mathrm{e}-05^{* *} \\
(1.45 \mathrm{e}-05)\end{array}$ & $\begin{array}{c}1.69 \mathrm{e}-05 \\
(1.07 \mathrm{e}-05)\end{array}$ & $\begin{array}{c}1.69 \mathrm{e}-05 \\
(1.12 \mathrm{e}-05)\end{array}$ \\
\hline Collateral sq. & $\begin{array}{c}-2.45 e-10 \\
(2.79 e-10)\end{array}$ & $\begin{array}{c}-1.07 \mathrm{e}-09 \\
(8.02 \mathrm{e}-10)\end{array}$ & $\begin{array}{c}-6.34 \mathrm{e}-10 \\
(3.88 \mathrm{e}-10)\end{array}$ & $\begin{array}{r}-3.39 \mathrm{e}-10 \\
(4.32 \mathrm{e}-10)\end{array}$ \\
\hline Assets value & $\begin{array}{c}1.02 \mathrm{e}-05 \\
(6.61 \mathrm{e}-06)\end{array}$ & $\begin{array}{c}2.56 \mathrm{e}-05^{* * * *} \\
(9.58 \mathrm{e}-06)\end{array}$ & $\begin{array}{c}2.23 \mathrm{e}-05^{* * *} \\
(6.54 \mathrm{e}-06)\end{array}$ & $\begin{array}{c}1.35 \mathrm{e}-05 \\
(9.96 \mathrm{e}-06)\end{array}$ \\
\hline Assets value sq. & $\begin{array}{c}-1.15 e-10 \\
(8.84 e-11)\end{array}$ & $\begin{array}{c}-5.13 \mathrm{e}-10^{* *} \\
(2.49 \mathrm{e}-10)\end{array}$ & $\begin{array}{c}-2.73 \mathrm{e}-10^{* * * *} \\
(9.98 \mathrm{e}-11)\end{array}$ & $\begin{array}{l}-2.68 \mathrm{e}-10 \\
(2.46 \mathrm{e}-10)\end{array}$ \\
\hline Declared profits & $\begin{array}{c}-4.86 e-05 \\
(3.58 \mathrm{e}-05)\end{array}$ & $\begin{array}{c}3.66 \mathrm{e}-05 \\
(4.10 \mathrm{e}-05)\end{array}$ & $\begin{array}{c}1.51 \mathrm{e}-05 \\
(3.30 \mathrm{e}-05)\end{array}$ & $\begin{array}{r}-5.79 \mathrm{e}-05 \\
(5.80 \mathrm{e}-05)\end{array}$ \\
\hline Declared profits sq. & $\begin{array}{c}3.48 \mathrm{e}-09 \\
(2.66 \mathrm{e}-09)\end{array}$ & $\begin{array}{c}-0 \\
(3.88 \mathrm{e}-09)\end{array}$ & $\begin{array}{c}-0 \\
(2.29 \mathrm{e}-09)\end{array}$ & $\begin{array}{c}9.45 \mathrm{e}-09 \\
(8.85 \mathrm{e}-09)\end{array}$ \\
\hline Location & $\begin{array}{l}-0.00988 \\
(0.0493)\end{array}$ & $\begin{array}{l}0.0817 * * \\
(0.0414)\end{array}$ & $\begin{array}{l}0.101 * * \\
(0.0396)\end{array}$ & $\begin{array}{l}0.00591 \\
(0.0460)\end{array}$ \\
\hline Guarantor & $\begin{array}{c}0.0941 \\
(0.0746)\end{array}$ & $\begin{array}{c}0.387 * * * \\
(0.0571)\end{array}$ & $\begin{array}{c}0.194 * * * \\
(0.0569)\end{array}$ & $\begin{array}{c}0.314 * * * \\
(0.0791)\end{array}$ \\
\hline Relationship & $\begin{array}{l}-0.0603 \\
(0.0460)\end{array}$ & $\begin{array}{c}-0.198 * * * \\
(0.0399)\end{array}$ & $\begin{array}{c}-0.0902^{* *} \\
(0.0384)\end{array}$ & $\begin{array}{c}-0.210^{* * * *} \\
(0.0429)\end{array}$ \\
\hline Purpose & $\begin{array}{c}-0.0331 \\
(0.0528)\end{array}$ & $\begin{array}{l}-0.0309 \\
(0.0437)\end{array}$ & $\begin{array}{c}0.0629 \\
(0.0424)\end{array}$ & $\begin{array}{l}-0.0794 \\
(0.0523)\end{array}$ \\
\hline Savings & $\begin{array}{c}-0.403 * * * \\
(0.0704)\end{array}$ & $\begin{array}{c}0.376 \\
(0.242)\end{array}$ & $\begin{array}{l}0.0774 \\
(0.186)\end{array}$ & $\begin{array}{c}-0.251 * * * * \\
(0.0335)\end{array}$ \\
\hline Maturity & $0.0218 * * *$ & $0.0202 * * *$ & $0.0159 * * *$ & $0.0149 * *$ \\
\hline
\end{tabular}




$$
(0.00542) \quad(0.00488) \quad(0.00414) \quad(0.00656)
$$

Type of MFI (base Governmental)

\begin{tabular}{|c|c|c|c|c|}
\hline \multicolumn{5}{|c|}{ Savings and Loans } \\
\hline \multirow[t]{2}{*}{ MFI 1} & $-0.230 * *$ & $-0.216 * * *$ & $-0.143 *$ & $-0.206 * * *$ \\
\hline & $(0.0990)$ & $(0.0521)$ & $(0.0755)$ & $(0.0490)$ \\
\hline \multirow[t]{2}{*}{ MFI 2} & $-0.369 * * *$ & $-0.283 * * *$ & $-0.376^{* * *}$ & $-0.168 * * *$ \\
\hline & $(0.0360)$ & $(0.0385)$ & $(0.0284)$ & $(0.0549)$ \\
\hline \multirow[t]{2}{*}{ MFI 3} & $-0.224 * *$ & $-0.224 * * *$ & $-0.183 * * *$ & $-0.221 * * *$ \\
\hline & $(0.0982)$ & $(0.0470)$ & $(0.0622)$ & $(0.0349)$ \\
\hline \multicolumn{5}{|l|}{$N G O$} \\
\hline \multirow[t]{2}{*}{$\overline{\mathrm{MFI}} 5$} & $-0.392 * * *$ & $-0.222 * * *$ & $-0.355^{* * *}$ & $-0.206 * * *$ \\
\hline & $(0.0317)$ & $(0.0570)$ & $(0.0342)$ & $(0.0454)$ \\
\hline \multirow[t]{2}{*}{ MFI 6} & 0.0173 & $-0.337 * * *$ & $-0.404 * * *$ & -0.0585 \\
\hline & $(0.240)$ & $(0.0220)$ & $(0.0435)$ & $(0.190)$ \\
\hline \multirow[t]{2}{*}{ MFI 7} & $-0.313 * * *$ & -0.0708 & $-0.195 * * *$ & -0.0407 \\
\hline & $(0.0715)$ & $(0.0873)$ & $(0.0708)$ & $(0.0949)$ \\
\hline \multirow[t]{2}{*}{ MFI 8} & $-0.402 * * *$ & $-0.140 * *$ & $-0.349 * * *$ & -0.116 \\
\hline & $(0.0383)$ & $(0.0710)$ & $(0.0337)$ & $(0.0710)$ \\
\hline \multirow[t]{2}{*}{ MFI 9} & -0.174 & $-0.161 * *$ & $-0.139 *$ & -0.118 \\
\hline & $(0.117)$ & $(0.0713)$ & $(0.0817)$ & $(0.0767)$ \\
\hline \multicolumn{5}{|l|}{ Rural and } \\
\hline \multicolumn{5}{|c|}{$\overline{\text { Community banks }}$} \\
\hline \multirow[t]{2}{*}{ MFI 10} & $-0.321 * * *$ & $-0.229 * * *$ & $-0.206^{* * *}$ & $-0.241 * * *$ \\
\hline & $(0.0562)$ & $(0.0553)$ & $(0.0747)$ & $(0.0327)$ \\
\hline \multirow[t]{2}{*}{ MFI 11} & -0.189 & -0.0953 & -0.0338 & -0.127 \\
\hline & $(0.124)$ & $(0.0937)$ & $(0.110)$ & $(0.0792)$ \\
\hline \multirow[t]{2}{*}{ MFI 12} & 0.176 & 0.101 & 0.219 & -0.0193 \\
\hline & $(0.205)$ & $(0.126)$ & $(0.142)$ & $(0.116)$ \\
\hline \multirow[t]{2}{*}{ MFI 13} & -0.136 & 0.0721 & -0.0365 & 0.0339 \\
\hline & $(0.124)$ & $(0.0818)$ & $(0.0837)$ & $(0.0940)$ \\
\hline \multirow[t]{2}{*}{ MFI 14} & -0.158 & -0.111 & -0.0747 & $-0.179 * * *$ \\
\hline & $(0.130)$ & $(0.0833)$ & $(0.0918)$ & $(0.0672)$ \\
\hline Observations & 622 & 807 & 877 & 544 \\
\hline
\end{tabular}

Notes: Standard errors in parentheses ${ }^{* *} \mathrm{p}<0.01,{ }^{* *} \mathrm{p}<0.05,{ }^{*} \mathrm{p}<0.1$

Marginal effects reported instead of coefficients. 


\subsection{Testing for Positive Discrimination in favor of women and young borrowers}

In order to test for positive discrimination, we resort to the Oaxaca-Blinder decomposition method shown in equation (3). Given the binary nature of our outcome variable (being rationed or not), in the previous section we used a non-linear model to analyze the determinants of the probability of being credit rationed. This means that the linear decomposition equation presented in equation (3) need to be manipulated in order to be adapted to a non-linear framework. Thus, following Fairlie (1999), the decomposition equation becomes now as follows:

$$
\hat{Y}_{n v}-\hat{Y}_{v}=\left[\sum_{i=1}^{N_{n v}} \frac{F\left(X_{i}^{n v} \hat{\beta}_{v}\right)}{N_{n v}}-\sum_{i=1}^{N_{v}} \frac{F\left(X_{i}^{v} \hat{\beta}_{v}\right)}{N_{v}}\right]-\left[\sum_{i=1}^{N_{n v}} \frac{F\left(X_{i}^{n v} \hat{\beta}_{n v}\right)}{N_{n v}}-\sum_{i=1}^{N_{n v}} \frac{F\left(X_{i}^{n v} \hat{\beta}_{v}\right)}{N_{n v}}\right],
$$

where the first term in brackets represents the part of the gap in credit rationing due to group differences in distributions of $\mathrm{X}$, and the second term represents the part due to differences in the group processes determining levels of Y. In other words, the first term refers to differences in endowments between the vulnerable (women/young) and the non-vulnerable (men/older), while the second term refers to differences in the treatment received by MFIs between both groups. F(•) represents the cumulative distribution function, and if we assume a linear function, then equation (4) becomes as equation (3).

Results of the decomposition are reported in columns (3) and (6) in table 4. As we already observed in table 2, the gap in the probability of being credit rationed is higher for men than for women, 3.7 percentage more, though it is not statistically significant. Results of the decomposition reveal that that men and women are treated differently by MFI in that regarding credit rationing. The endowments component is of -0.062, which means that men and women are endowed with different characteristics. This result indicates that if both men and women where endowed with same characteristics $\left(\mathrm{X}_{\mathrm{men}}=\mathrm{X}_{\text {women }}\right)$, the gap will increase up to 9.9 percentage points (0.037-(- 
0,062)) against men. Analogously, the reported discriminatory component is of 0.099, almost three times the size of the gap, which indicates that if men and women were not treated differently $\left(\beta_{\mathrm{men}}=\beta_{\text {women }}\right)$, the gap in the probability of being credit rationed would be -6.2 percentage points (0.037-0.099) higher for women than for men. This result indicates that there exists strong positive discrimination in favor of women.

For the group of youth, we also observe positive discrimination. The probability of being credit rationed is 12 percentage points smaller for youth borrowers than for their older counterparts. The endowments component is practically null (-0.006), which means that youth and older borrowers are endowed practically with the same characteristics $\left(\mathrm{X}_{\mathrm{youth}}=\mathrm{X}_{\text {older }}\right)$, therefore the gap is totally attributable to a different treatment by MFIs. If youth and older borrowers where not treated differently by MFIs $\left(\beta_{\text {youth }}=\beta_{\text {older }}\right)$ the gap in the probability of being credit rationed would be -0.6 percentage points (0.12-0.126) smaller for older borrowers. That is, the gap would be practically removed. This result indicates again strong positive discrimination in favor of young borrowers.

To better understand the implications of our results, we will resort to the counterfactual analysis by means of the following expressions:

$$
\begin{aligned}
& \dot{\mathrm{P}}_{\mathrm{nv}}^{\mathrm{v}}(\mathrm{y}=1)=\Phi\left(\overline{\mathrm{X}}^{\mathrm{v}} \hat{\beta}_{\mathrm{nv}}\right) \\
& \ddot{\mathrm{P}}_{\mathrm{v}}^{\mathrm{nv}}(\mathrm{y}=1)=\Phi\left(\overline{\mathrm{X}}^{\mathrm{nv}} \hat{\beta}_{\mathrm{v}}\right)
\end{aligned}
$$

where $\Phi(\bullet)$ is the cumulative normal distribution of the inner argument, and the subscript and superscript $v$ refers to the vulnerable targeted group (female/youth) and $n v$ refers to the nonvulnerable group (male/older).

With Equation (4), we simulate which would be the probability of being credit rationed if the average vulnerable borrower $\left(\overline{\mathrm{X}}^{\mathrm{v}}\right)$ was treated as his/her average non-vulnerable counterpart 
$\left(\hat{\beta}_{\mathrm{nv}}\right)$. Analogously, equation (5) simulates the opposite situation, that is, what would be the probability of being credit rationed if the average non-vulnerable borrower $\left(\overline{\mathrm{X}}^{\mathrm{nv}}\right)$ was treated as his/her average vulnerable counterpart $\left(\hat{\beta}_{v}\right)$. According to the decomposition analysis, what we should expect is that vulnerable borrowers treated as the non-vulnerable should increase their probability of being credit rationed, while this probability should decrease for the non-vulnerable if they were treated as the vulnerable. Results of the counterfactual analysis are reported in the last row of table 4 .

In column (1) we show the counterfactual for the probability of being credit rationed for female treated as male borrowers. This counterfactual probability is of 0.43 , which is 12 percentage points higher than the predicted probability for women (0.31). Analogously, if male borrowers are treated as their female counterparts (column 2), their counterfactual probability is 0.324, which is 4 percentage than the observed probability for male borrowers. Counterfactual analysis for youth-older borrowers also report similar results. That is, if young borrowers were treated as their older counterparts (column 4), the counterfactual probability of being credit rationed would be of $0.385,7$ percentage points than the observed probability (0.317). On the contrary, if older borrowers were treated as their young counterparts (column 5), their probability of being credit rationed would be of 0.392, 6 percentage points higher than their observed probability (0.332). These results are in line with the evidence of positive discrimination in favor of female and young borrowers. 
Table 4: Decomposition and Counterfactual Analysis

\begin{tabular}{|c|c|c|c|c|c|c|}
\hline & \multirow{2}{*}{$\begin{array}{r}\text { (1) } \\
\text { Female }\end{array}$} & $(2)$ & \multirow[t]{2}{*}{ (3) } & (4) & \multirow{2}{*}{$\frac{(5)}{\text { Older }}$} & \multirow[t]{2}{*}{ (6) } \\
\hline & & Male & & Young & & \\
\hline $\mathrm{P}($ ration=1), observed & 0,346 & 0,383 & \multirow{3}{*}{$\begin{array}{r}0,037 \\
1,44\end{array}$} & 0,288 & 0,408 & \multirow{3}{*}{$\begin{array}{r}0,12 \\
4.63^{* * *}\end{array}$} \\
\hline \multicolumn{2}{|c|}{$\begin{array}{l}\text { Gap (Endoments+Discrimination) } \\
\text { t-test }\left(\mathrm{H}_{0}: \mathrm{Gap}=\mathrm{O}\right)\end{array}$} & & & & & \\
\hline $\mathrm{P}($ ration $=1)$, predicted & 0.310 & 0,363 & & 0,317 & 0.392 & \\
\hline$\frac{\text { Decomposition results }}{\text { Endowments }}$ & & & $\begin{array}{r}-0,06 \\
-168 \%\end{array}$ & & & $\begin{array}{r}-0,006 \\
-5 \%\end{array}$ \\
\hline Discrimination & & & $\begin{array}{l}0,099 \\
268 \%\end{array}$ & & & $\begin{array}{l}0,126 \\
105 \%\end{array}$ \\
\hline
\end{tabular}

\section{Counterfactual analysis}

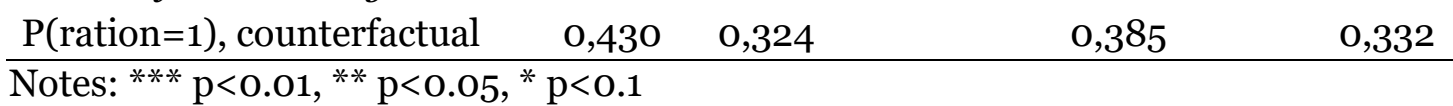

\section{Conclusions and Policy Implications}

Access to credit has become a huge problem to micro and small entrepreneurs and the groups that are badly affected are the vulnerable who are mostly made up of women and the youth, both in the formal and the informal sectors. There has been various intervention programmes aimed at empowering the vulnerable through the provision of the needed resources that will enable them to be employed and earn sustainable incomes and live a meaningful and dignified lives. One of the major policies aimed at providing access to credit to these vulnerable groups is the Ghana Microfinance Policy which enjoins the microfinance institutions to give priority to the vulnerable in their administering of credit. Our research was set up to determine the extent to which the operations of the microfinance companies in the microfinance market in Ghana are influenced by the Ghana's Microfinance Policy. We observed that whereas the microfinance companies are using individual and loan characteristics to ration credit towards male and adult entrepreneurs this approach is very minimal and relaxed towards female and young entrepreneurs. Thus, the 
rationing behavior of the microfinance companies favors female and young entrepreneurs and this favoritism is not influenced by their group endowments.

Our results imply that the microfinance companies' operations in Ghana are in line with the Ghana Microfinance Policy. Though the policy is in the right direction, there is the need to complement it by introducing and intensifying policies that seek to give skill training and accessible education to these vulnerable groups to enable them to effectively and efficiently utilize the funds being provided them. Making microcredit readily and easily accessible to these groups without proper entrepreneurial skills and formal education, will not achieve the desired results. There is therefore the need to making education and training go hand in hand with the supply of investible funds. It is also recommended that current government intervention programmes be given legal backing and as much as possible be depoliticized. 


\section{References}

Agarwal, B. (2003). Gender and land rights revisited: Exploring new prospects via the state, family, and market. Journal of Agrarian Change, 3 (1), 184-224

Alberto, F.A., Francesca, L., and Paolo, E.M. (2013). Do women pay more credit? Evidence from Italy. Journal of the European Economic Association, 11 (1), 45-66

Alexander, M., Oleksandr, T., and Dorethea, S. (2009). Entrepreneurs' gender and financial constraints: evidence from international data. Journal of Comparative Economics, $37,270-286$

Andrea, B., Alexander, B., and Alberto, Z. (2010). Does gender matter in bank-firm relationship? Evidence from small business lending. Journal of Banking and Finance, $34,2968-2984$

Arrow, K. (1973). The theory of discrimination. in: Aschenfelter, O., Rees, A. (Eds.), Discrimination in labor markets. Princeton University Press, Princeton, NJ, 3-33.

Asiedu, E., Kanyama, I.K., Ndikumana, L., and Nti-Addae, A. (2013). Access to credit by firms in sub-Saharan Africa: How relevant is gender. American Economic Review, 103 (3), 293-297.

Aterido, R., Beck. T., and Lacovone, L. (2011). Gender and finder in sub-Saharan Africa. Are women disadvantaged? World Bank Policy Research Working Paper 5571. World Bank, Africa Region

Banerjee, A., Duflo, E., Glennester, R., and Kinnan, C. (2010). The miracle of microfinance? Evidence from randomized evaluation. BREAD Working Paper No. 278

Becker, G.S., (1957). The Economics of Discrimination. University Press, Chicago.

Benjamin Otoo. (2012). Micro credit for micro enterprise: a study of women "petty" traders in central region of Ghana. International journal of scientific research in education, 5(3) 247-259 
Berger, A.N., and Udell, G.F. (1998). The economics of small business finance: The roles of private equity and debt markets in the financial growth cycle. Journal of Banking and Finance, 22 (6-8), 613-673.

Blinder, A.S. (1973). Wage discrimination: reduced form and structural estimates. The Journal of Human Resources, 8, 436-455

Brown, W. (2001). Micro insurance-the risks, perils and opportunities. Small Enterprise Development, 12(1), 11-24

Canton, E., Grilo, I., and Monteagudo, J. (2010). Investigating the perception of credit constraints in the European Union. ERIM Report. Research Series in Management. Netherlands.

Cavalluzzo, K.S., Cavalluzzo, L.C., and Wolken, J.D. (2002). Competition, small business financing, and discrimination: evidence from a new survey. Journal of Business, 75 (4), 641-680.

Consultative Group to Assist the Poor (CGAP) (2012). Annual Report. Washington DC

Consultative Group to Assist the Poor (CGAP) and the United Nations Capital Development Fund (UNCDF). (2006). The New Vision of Microfinance: Financial Services for the Poor. Donor Training, Washington, DC:CGAP.

Cornell Empowerment Group. (1989). Empowerment and family support. Networking Bulleting, 1(2), 1-23

Cotton, J. (1988). On the decomposition of wage differentials. Review of Economics and Statistics 70 (2), 236-43

Darvas, P. and Palmer, R. (2014). Demand and supply of skills in Ghana. How can training programme improve employment and productivity? Washington DC: World Bank

De Mel, S., D. McKenzie, and Woodruff,C. (2009). Are women more credit constrained? Experimental evidence on gender and microenterprise returns. American Economic Journal: Applied Economics, 1 (3), 1-32. 
Evans, D.S., Jovanovic, B. (1989). An estimated model of entrepreneurial choice under liquidity constraints. Journal of Political Economy, 97 (4), 808-827.

Fazzari, S., Hubbard, R.G., and Petersen, B.C. (1988). Financing constraints and corporate investment. Brookings Papers on Economic Activity, 78, 141-195.

Fafchamps, M., McKenzie, D., Quinn, R. S., and Woodruff, C. (2011). When is capital enough to get female micro enterprise growing? Evidence from a randomized experiment in Ghana. National Bureau of Economic Research Working Paper 17207

Fafchamps, M. (2000). "Ethnicity and credit in African manufacturing", Journal of Development Economics, 61(1), 205-235.

Fafchamps, M., McKenzie, D., Quinn, S., and Woodruff, C. (2014). Microenterprise Growth and the Flypaper Effect: Evidence from a Randomized Experiment in Ghana. Journal of Development Economics, 106, 211-226.

Fletschner, D. (2008). Women's access to credit: does it matter for household efficiency? American Journal of Agricultural Economics, 90 (3), 669.683.

Fletschner, D. (2009). Rural women's access to credit: market imperfections and intrahousehold dynamics. World Development Report, 37 ( 3), 618-631

Khalid, S.M, and Andrew, E.T. (2009). Gender characteristics of the determinants of access to formal credit in rural Zanzibar. Journal of Savings and Development, 2, 95-111.

Ghana Microfinance Network (GHAMFIN). (2011). Performance benchmarks of microfinance institutions in Ghana, Accra

Ghana Statistical Service. (2007). Pattern and trends in poverty in Ghana, 1991 - 2006, Accra.

Ghana Statistical Service. (2013). Ghana living standards survey report of the sixth round (GLSS6), Accra

Gyampo, R. (2012). Youth participation in youth programmes: The case of Ghana's national youth employment programme, Journal of Pan African Studies, 5 (5), 13-28 
Henrik, H., and John, R. (2011). Another perspective on gender specific access to credit in Africa. FOI Working Paper, 2011(14)

Hansen, H., and Rand, J. (2014). The myth of female credit discrimination in African manufacturing. The Journal of Development Studies, 50 (1) 81-96

Hansen, H., and Rand, J. (2014). Estimates of gender differences in firm's access to credit in sub-Saharan Africa. Economic Letters, 123, 374-377.

ILO. (2007). Small change, big changes: Women and microfinance. Geneva, Switzerland: International Labour Organizations.

ILO. (2011). Assessment for the environment for the development of women's entrepreneurship in Cameroon, Mali, Nigeria, Rwanda and Senegal

ISSER. (2012). Institute of Statistical, Social and Economic Research). Ghana social development outlook, 2012, University of Ghana. Accra.

Jaffee, D. M. and Russel, T. (1976). 'Imperfect information uncertainty and credit rationing'. Quarterly Journal of Economics, 90, 651-66.

Karlan, D. and Jonathan, Z. (2010). Expanding micro enterprise credit access: using randomized supply decisions to estimate the impacts in Manila. Mimeo, Yale University

Klapp, L. F., and Parker, S. C. (2010). "Gender and the business environment for new firm creation”, World Bank Research Observer, doi:10.1093/wbro/lkpo32

Korboe, D. (2014). Youth development intervention in Ghana: policy and practice. IBIS education for development, Accra, Ghana.

Lafourcade, A.J., Isern, P., Mwangi, P., and Brown, M. (2005). 'Overview of outreach and financial performance of microfinance institutions in africa', microfinance information exchange (MIX), CGAP. Washington DC

Lapar, M.L.A. and Graham, D.H. (1988). "Credit rationing under a deregulated financial system” Working Paper Series No. 88 - 19 
Ledgerwood, J. (1999). Microfinance handbook, an institutional and financial perspective. Washington, DC

Leora, F.K., and Simon, C.P., (2011). Gender and the business environment for new firm creation. The World Bank Research Observer, 26 (2), 237-257.

Mateut, S and Mizen, P. (2003). Trade credit \& bank lending: an investigation into determinants of UK manufacturing firms access to trade credit. EUI Workshop Paper ECO No 200/3.University of Nottingham, United Kingdom

Microfinance Information Exchange Inc. (MIX) Report, 2012

Mijid, N., and Bernask, A. (2013). Gender and credit rationing of small businesses. The Social Science Journal, 50, 55-65

Neumark, D. (1988). Employers' discriminatory behavior and the estimation of wage discrimination. Journal of Human Resources, 23(3), 279-95

Ngimwa, P., Ocholla, D.N., and Ojiambo, J.B. (1997). Media accessibility and utilization by Kenyan rural women. International Information and Library Review, 9, 45-66

Nukunya,G.K. (2003). Tradition and change in Ghana. Second and enlarged edition, Accra, Universities Press.

Oaxaca,R. (1973). Male-female wage differentials in urban labor markets. International Economic Review, 14, 693-709

Ospina, R. I. (1998). Perspectiva de género en la mision rural: para dotar de poder a las mujeres, mision rural proyecto proequidad GTZ/ DNP, Santa fe de Bogota' , Colombia.

O’ Donnel, O., Doorslaer, V. E., Wagstaff, A., and Lindelow, M. (2008). Analyzing health equity using household survey data. WBI learning resources series. The World Bank, Washington D.C

Pariente, W. (2005). Financial demand and access to credit in low - income areas of Rio de Janeiro, Brazil. Pesquisa and Debate, 16:2, (28), 150-173 
Perkins, D.D., and Zimmerman, M.M. (1995). Empowerment theory, research and application. an introduction to a special issue. An American Journal of Community Psychology, 23, 569-576

Phelps, E.S. (1972). The statistical theory of racism and sexism. American Economic Review, $62(4), 659-661$.

Phylis, M., Simon, T.K., and Charles, I. N. (2014). Challenges facing women entrepreneurs in accessing business finance in Kenya: the case of Ruiri township, Kiambu county. IOSR

Journal of Business and Management, 16 (4), 83-91

Rappaport, J. (1981). In praise of paradox: asocial policy of empowerment over prevention. American Journal of Community Psychology, 9, 1-25

Rappaport, J. (1984). Studies in empowerment: an introduction to the issue. Prevention in Human Services, 3, 1-7

Reimers, C.W. (1983). Labor market discrimination against Hispanic and black men. Review of Economics and Statistics, 65(4), 570-79

Stein, P., Goland, T., and Schiff, R. (2010). Two trillion and still counting: assessing the credit gap for micro, small and medium-size enterprises in developing world, McKinsey and company and IFC: Washington, DC.

Stiglitz, J. E., and Weiss, A. (1981). Credit rationing in markets with imperfect information. The American Economic Review, 71(3), 393-410.

Suresh, D.M., David, M., and Christopher, W. (2009). Are women more credit rationed? Experimental evidence on gender and microenterprise returns. American Economic Journal: Applied Economics 1(3), 1-32

Tabi, A. J., and Fomba, E. M. (2013). Comparative business practices and productivity performance between family and non-family firms: perceptions and poverty reduction effects in cameroon. Investment Climate and Business Environment Research Fund Report No. 48/13 
UNDP. (2007). Human development report 2007. New York, NY.

World Development Report, (2012). Gender equality and development. World Bank, Washington, DC.

Zeller, M.(1994). Determinants of credit rationing: a study of informal lenders and formal credit groups in Madagascar. World Development Report, 22 (12), 1895- 1907

Zimmerman, M.A., and Warschausky, S. (1991). Empowerment theory of rehabilitation research: conceptual and methodological issues. Rehabilitation Psychology, 43, 316) 